\title{
Effectiveness, economical and safety aspects of growth hormone (GH) therapy in growth promoting doses in patients with isolated GH deficiency after the attainment of near-final height. Is there a need to modify the criteria of therapy withdrawal?
}

Skuteczność, aspekty ekonomiczne i bezpieczeństwo terapii hormonem wzrostu w dawkach promujących wzrastanie u pacjentów z izolowaną somatotropinową niedoczynnością przysadki w końcowej fazie leczenia przed uzyskaniem wzrostu końcowego. Czy należy zmodyfikować kryteria zakończenia terapii?

${ }^{1}$ Joanna Smyczyńska, ${ }^{2}$ Maciej Hilczer, ${ }^{2,3}$ Andrzej Lewinski, ${ }^{4}$ Urszula Smyczyńska, ${ }^{2,5}$ Renata Stawerska

${ }^{1}$ Department of Pediatrics, Diabetology Endocrinology and Nephrology, Medical University of Lodz, Poland ${ }^{2}$ Department of Endocrinology and Metabolic Diseases, Polish Mother's Memorial Hospital - Research Institute in Lodz, Poland

${ }^{3}$ Department of Endocrinology and Metabolic Diseases, Medical University of Lodz, Poland ${ }^{4}$ Department of Biostatistics and Translational Medicine, Medical University of Lodz, Poland ${ }^{5}$ Department of Pediatric Endocrinology, Medical University of Lodz, Poland

\footnotetext{
Abstract

Introduction: Apart from growth promotion, growth hormone $(\mathrm{GH})$ has important metabolic effects. Patients with severe $\mathrm{GH}$ deficiency (GHD) should be treated with GH throughout life. Current criteria for growth promoting therapy withdrawal in Poland differ from the latest recommendations.

Aim of the study: To assess cost-effectiveness and safety of continuation of GH therapy in growth promoting doses in patients with isolated GHD after the attainment of near-final height (near-FH) and the incidence of persistent GHD after the therapy withdrawal. Material and methods: 160 children with isolated GHD (height $<3$ centile, GH peak $<10.0 \mu \mathrm{g} /$ ), who continued GH therapy for growth promotion after the attainment of near-FH (height velocity $<2.5 \mathrm{~cm} /$ year, bone age $\geq 16$ years in boys, $\geq 14$ years in girls). Clinical endpoints were: absolute height gain after near-FH, GH dose - cumulative and recalculated for additional $1.0 \mathrm{~cm}$ of height, number of injections, incidence of increased IGF-1 concentrations (IGF-1 SDS > 2.0) at near-FH and incidence of severe GHD in retesting (performed in 62 patients).

Results: Height gain after near-FH was $1.1 \pm 0.8 \mathrm{~cm}$ in boys and $1.0 \pm 0.8$ in girls. Increase of height by $1.0 \mathrm{~cm}$ required on average $487 \mathrm{mg}$ of GH (264 injections). IGF-1 concentrations at near-FH were increased in 39 patients, with no clinical side effects. None of the patients retested had $\mathrm{GH}$ peak $<3.0 \mu \mathrm{g} / \mathrm{l}$, while $37(60 \%)$ had $\mathrm{GH}$ peak $>10.0 \mu \mathrm{g} / \mathrm{l}$.

Conclusions: There is no rationale to continue GH therapy in growth promoting doses in the patients with isolated GHD after fulfilling the criteria of near-FH.

Key words:

growth hormone deficiency, recombinant growth hormone, insulin-like growth factor-1, treatment efficacy, final height.

\section{Streszczenie}

Wprowadzenie: Obok promocji wzrastania hormon wzrostu $(\mathrm{GH})$ wykazuje istotne działania metaboliczne. Pacjenci z ciężkim niedoborem GH (GHD) powinni być leczeni GH przez całe życie. Obecne kryteria zakończenia terapii promującej wzrastanie w Polsce różnią się od najnowszych rekomendacji.

Cel pracy: Ocena skuteczności, kosztów i bezpieczeństwa terapii GH promującej wzrastanie po osiągnięciu tzw. near-final height (near-FH) u pacjentów z izolowanym GHD oraz częstości występowania trwałego GHD po zakończeniu leczenia.
} 
Materiał i metody: 160 dzieci z izolowanym GHD (wzrost < 3. centyla, wydzielanie GH < $10.0 \mu \mathrm{g} /$ ), kontynuujących terapię GH w celu promocji wzrastania po osiągnięciu near-FH (tempo wrastania $<2,5 \mathrm{~cm} /$ rok, wiek kostny $\geq 16$ lat u chłopców i $\geq 14$ lat u dziewcząt). Końcowymi punktami klinicznymi były: całkowity przyrost wzrostu po osiągnięciu near-FH, dawka GH - skumulowana i przeliczona w odniesieniu do uzyskania dodatkowego 1,0 cm wzrostu, liczba iniekcji, częstość podwyższonych stężeń IGF-1 (IGF-1 SDS > 2,0) w momencie osiągnięcia near-FH i częstość ciężkiego GHD podczas retestingu (wykonanego u 62 pacjentów).

Wyniki: Całkowity przyrost wzrostu po uzyskaniu near-FH wynosił 1,1 $\pm 0,8 \mathrm{~cm}$ u chłopców i 1,0 \pm 0 ,8 cm u dziewcząt. Uzyskanie przyrostu wzrostu o 1,0 cm wymagało podania średnio 487 mg GH w 264 iniekcjach. Stężenia IGF-1 w momencie osiągnięcia nearFH były podwyższone u 39 pacjentów, ale nie obserwowano działań niepożądanych terapii. Podczas retestingu u żadnego z pacjentów nie stwierdzono wydzielania $\mathrm{GH}<3,0 \mu \mathrm{g} / \mathrm{l}$, podczas gdy u 37 (60\%) uzyskano wyrzut $\mathrm{GH}>10,0 \mu \mathrm{g} / \mathrm{l}$.

Wnioski: Kontynuacja terapii GH w dawkach promujących wzrastanie u pacjentów z izolowanym GHD po spełnieniu kryteriów near-FH nie wydaje się uzasadniona.

\section{Słowa kluczowe:}

somatotropinowa niedoczynność przysadki, rekombinowany hormon wzrostu, insulinopodobny czynnik wzrostowy 1, efektywność terapii, wzrost końcowy.

\section{Introduction}

Growth hormone $(\mathrm{GH})$ deficiency $(\mathrm{GHD})$ in children with short stature is the main indication to treatment with recombinant human $\mathrm{GH}$ (rhGH) and the main goal of this therapy is to attain normal final height $(\mathrm{FH})$. Along with growth promotion, $\mathrm{GH}$ has a number of metabolic effects, which manifest throughout all human life. During a few years after completion of linear growth, in so-called transition period, $\mathrm{GH}$ is necessary to obtain normal peak bone mass $[1,2]$. Severe GHD in adults is associated with decreased bone mineral density and increased risk of fractures, reduced lean body mass, decreased muscle strength, increased visceral fat tissue and disorders of carbohydrate and lipid metabolism which are important risk factors of cardiovascular diseases, and with deterioration of the quality of life [3-5]. Thus, the patients with confirmed severe GHD may require continuation of $\mathrm{rhGH}$ therapy in adulthood.

The therapy started in childhood is usually withdrawn when the patients complete their linear growth that manifests as a significant decrease of height velocity $(\mathrm{HV})$, related to advanced bone maturation. After the wash-out period, all the patients should have performed reassessment of $\mathrm{GH}$ secretion (so-called retesting) with appropriate diagnostic criteria [6, 7]. More than 20 years ago it was recommended in the Consensus of Growth Hormone Research Society (GHRS) [8] that such retesting should be performed after the attainment of $\mathrm{FH}$. Severe GHD was defined there as GH peak in insulin tolerance test (ITT) below $3 \mu \mathrm{g} / \mathrm{l}$ [8]. However, in 2005, Clayton et al. [9] suggested that this cut-off value might be too low during late puberty. In the updated Consensus Guidelines concerning GHD in adults [10], the cut-off for GH peak in ITT on the level of $6 \mu \mathrm{g} / \mathrm{l}$ has been established for patients in transition period, however with a suggestion of its further validation.

In 2016, Grimberg et al. [11] have recommended to stop rhGH treatment at pediatric doses in the patients whose HV had decelerated below 2-2.5 cm/year and bone age (BA) was estimated as 16-17 years in boys, and 14-15 years in girls. Continuation of therapy with lower rhGH doses in such patients could be beneficial only in the case of persistent GHD.

In Poland, according to the description of Treatment Program for Children with GHD, rhGH therapy should be continued up to the attainment BA over 18 years in boys and over 16 years in girls, unless there are complications of treatment or patients disagree to continue daily injections (the withdrawal of treatment due to slow HV is provided only for patients with BA below 16 years in boys and 14 years in girls) [12]. Otherwise, according to Summaries of Product Characteristics of rhGH preparations available in Poland, somatropin should not be used for growth promotion in children with fused epiphyses, defined in the same documents as attained BA over 16 years in boys and over 14 years in girls. Since November 2020 it is also approved in Poland to qualify the patients with severe GHD, confirmed after completion of growth promotion, to rhGH therapy in "metabolic" doses [13]. Thus, rhGH therapy for growth promotion may be withdrawn in accordance with current recommendations [11] with no risk of unfavorable metabolic consequences. However, taking into account that $\mathrm{GH}$ secretion sufficient for appropriate regulation of metabolic processes may be insufficient for linear growth, it seems important to assess the effectiveness of rhGH therapy continued in growth-promoting doses after the attainment of near-FH.

Additionally, it is recommended that rhGH doses should be lowered during growth promotion due to safety reasons if IGF-1 concentration exceeds upper limit of the laboratory-defined normal range for age and pubertal stage of the patient [11]. Thus, IGF-1 secretion during treatment after attainment of near$\mathrm{FH}$ is also taken into account in present study.

The aim of present study was to assess cost-effectiveness and safety aspects of rhGH therapy in patients with isolated GHD between the attainment of near-FH according to the criteria of Grimberg et al. [11] and the therapy withdrawal in concordance with current Polish criteria, as well as the incidence of persistent GHD at retesting in these patients.

\section{Material and methods}

\section{Inclusion criteria and the study protocol}

Retrospective analysis comprised the data of 160 patients (97 boys, 63 girls) with isolated GHD diagnosed in childhood, treated with rhGH, who continued growth promoting therapy after the attainment of near- $\mathrm{FH}$ and completed it during last 10 years. The studied group included 148 patients with classic 
form of $\mathrm{GHD}$, i.e. $\mathrm{GH}$ peak in standard stimulation tests with clonidine $\left(0.15 \mathrm{mg} / \mathrm{m}^{2}\right.$, orally) and with glucagon $(0.03 \mathrm{mg} / \mathrm{kg}$, not exceeding $1.0 \mathrm{mg}$, i.m.) below $10.0 \mu \mathrm{g} / \mathrm{l}$ (GHD Group) and 12 patients with neurosecretory dysfunction of $\mathrm{GH}$ secretion, i.e. with $\mathrm{GH}$ peak over $10.0 \mu \mathrm{g} / \mathrm{l}$ after pharmacological stimulation (as above) but below $10.0 \mu \mathrm{g} / \mathrm{l}$ during 3 hours after falling asleep, qualified to treatment many years ago (NSD Group).

Inclusion criteria at therapy onset were: body height below $3^{\text {rd }}$ centile for age and sex, according to centile charts for Polish children [14]; slow HV (decreasing centile position of height during at least 6 months of observation); delayed BA, according to Greulich-Pyle standards [15] with respect to chronological age (CA); known IGF-1 concentration; no abnormalities in pituitary region in magnetic resonance (except for isolated anterior pituitary hypoplasia); normal female karyotype (46,XX) in girls. The heights of parents were available for 159 patients. Exclusion criteria were: known or highly suspected genetic syndromes or skeletal dysplasiae, multiple pituitary hormone deficiencies, disorders of other endocrine glands (except for well-controlled primary hypothyroidism), malnutrition, malignancies, brain injuries, any chronic diseases and therapies that might disturb growth that occurred before or during rhGH treatment, documented unsystematic therapy. It should be noted here that complete data concerning rhGH therapy was available for 365 patients with isolated GHD who completed treatment during this time, however 195 of them have not been treated after the attainment of near$\mathrm{FH}$, while other 10 did not meet any of current inclusion criteria.

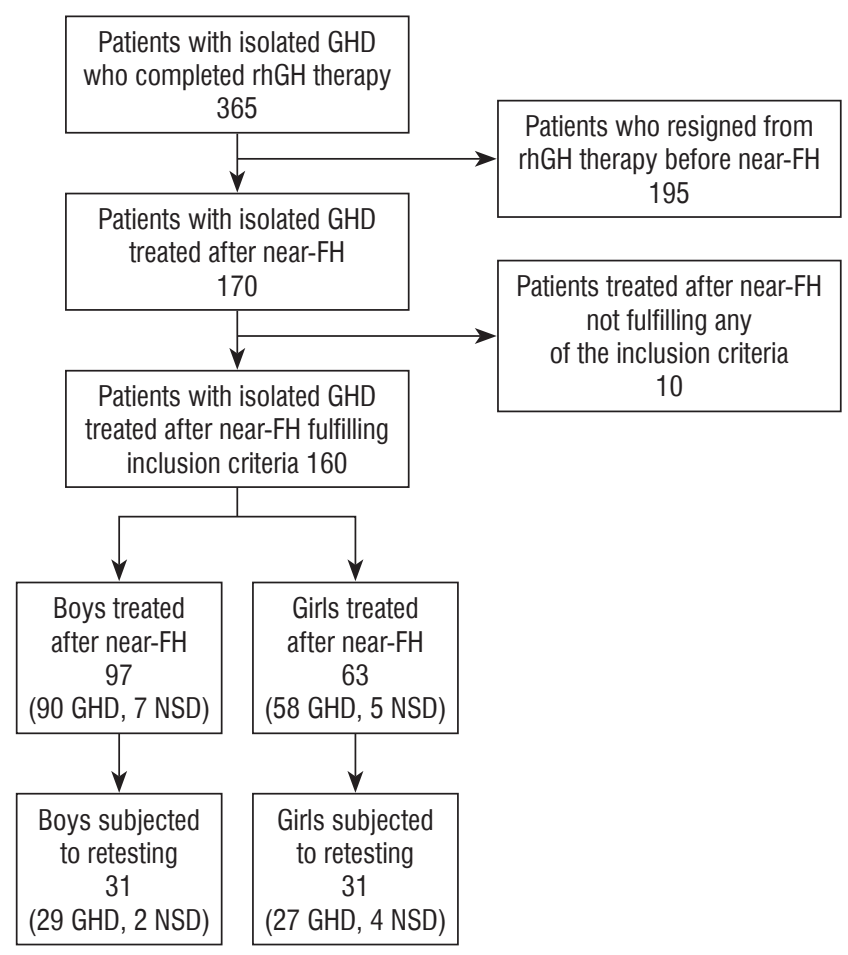

Figure 1. Flowchart of data collection on patients with isolated GHD who completed rhGH therapy
The patients were treated with $\mathrm{rhGH}$ at standard doses (0.17-0.33 mg/kg/week), in daily subcutaneous injections, performed before falling asleep. During treatment patients' height was measured every 3-6 months, pubertal stage and thyroid function were assessed every 6 months, IGF-1 levels and BA at least once a year.

Criteria of near- $\mathrm{FH}$ included decrease of $\mathrm{HV}$ below $2.5 \mathrm{~cm} /$ year during last 6 months, together with attained BA at least 16 years in boys and at least 14 years in girls.

Sole criterion for the therapy withdrawal was not entirely consistent with the description of Therapeutic Program for children [12] and included patient's BA at least (not over) 18 years for boys and at least (not over) 16 years in girls.

For the patients who decided to stop treatment after the attainment of near-FH but before fulfilling the withdrawal criteria, the attained body height and the latest available BA and IGF-1 concentration were taken into account in analyses.

The therapy duration after the attainment of near-FH and a weekly rhGH dose were known for each patient, enabling to calculate the number of injections and the cumulative rhGH dose during this time period.

All the patients who completed rhGH therapy (except for ones lost to follow-up) were asked for retesting of their $\mathrm{GH}$ secretory status at least 1 month after completion of treatment, including ITT with insulin dose $0.1 \mathrm{IU} / \mathrm{kg}$, i.v. and measurement of IGF-1 concentration. Second stimulation test (with clonidine or glucagon, the same protocols as in childhood) was performed in the case of decreased GH peak in ITT. The cut-off values of $\mathrm{GH}$ peak for children $(10.0 \mu \mathrm{g} / \mathrm{l})$, for transition period $(6.0 \mu \mathrm{g} / \mathrm{l})$ and for adults $(3.0 \mu \mathrm{g} / \mathrm{l})$ were used to assess the incidence of persistent and transient GHD.

Bearing in mind the physiological differences between the timing of bone maturation and completion of linear growth in boys and girls, as well as possible differences between the patients with classic GHD and with NSD, all the analyses were performed with respect to patients' sex and pre-treatment diagnosis.

For details concerning data collection see Figure 1.

\section{Clinical endpoints}

Primary clinical endpoints concerning $\mathrm{rhGH}$ therapy effectiveness after the attainment of near-FH were:

1. Increase of patient's height $(\Delta \mathrm{Ht})$ and height SDS $(\Delta \mathrm{HtSDS})$ between the attainment near-FH and the therapy withdrawal.

2. Mean rhGH dose and number of injections necessary for $1.0 \mathrm{~cm}$ of linear growth.

The main clinical endpoint for the assessment of safety of growth promoting therapy in its final phase was the proportion of patients with increased IGF-1 concentrations (i.e. with IGF-1 SDS over 2.0).

The main clinical endpoint concerning the indications to rhGH administration beyond growth promotion was the proportion of patients with confirmed GHD in retesting, according to different cut-off values for $\mathrm{GH}$ peak $(3.0 \mu \mathrm{g} / \mathrm{l}, 6.0 \mu \mathrm{g} / \mathrm{l}$ and $10.0 \mu \mathrm{g} / \mathrm{l}$ ), and of ones with IGF-1 deficiency (IGF-1 SDS below -2.0) during retesting. 


\section{Auxological measurements}

Patients' height was measured with an accuracy of $0.1 \mathrm{~cm}$, using Harpenden stadiometer, height SDS for chronological age (CA) was calculated according to Polish reference data [14] for each patient at each time point. Target height (TH) was calculated as the mean of heights of parents $+6.5 \mathrm{~cm}$ for boys and $-6.5 \mathrm{~cm}$ for girls and expressed as TH SDS using the same reference data [14]. Bone age was always assessed according to Greulich-Pyle standards [15].

\section{Laboratory assays}

Both GH and IGF-1 concentrations were measured with IMMULITE 2000 system. Normative data for IGF-1 provided by Elmlinger et al. [16] were used, with appropriate recalculation of laboratory results obtained since 2017 , due to the restandardization of assays.

\section{Statistical analysis}

Descriptive statistics included number of patients in particular groups and the values of the analyzed parameters, expressed as mean $\pm \mathrm{SD}$. For comparison between different groups, all age- and sex-dependent variables were expressed as SDS values. As the distributions of most variables were different from normal distribution, non-parametric statistical tests were applied. Mann-Whitney $U$ test was used for comparisons between independent samples, while Wilcoxon test for dependent samples. Spearman's correlation coefficients were calculated where reported.

\section{Results}

In the whole group of patients qualified to the study, the male predominance (60.6\%) was observed. At the therapy onset girls were significantly younger than boys $(p<0.001)$, which was associated with significantly younger BA $(p<0.05)$, while BA delay (BA/CA ratio) was similar in boys and girls. Absolute and parentally-adjusted deficit of height was similar in boys and girls. Statistically significant differences in both $\mathrm{GH}$ peak and IGF-1 SDS between boys than in girls were observed ( $p=0.004$ and $p<0.001$, respectively), however mean $\mathrm{GH}$ peak was only $0.8 \mu \mathrm{g} / \mathrm{l}$ higher in girls than in boys, which is not a clinically significant difference. Despite significantly lower $\mathrm{GH}$ peak in GHD Group than in NSD Group, height SDS at therapy onset was significantly lower in NSD than in GHD $(p=0.01)$ that may be considered a kind of bias as among the patients with NSD only ones with the most severe deficit of height were qualified to $\mathrm{rhGH}$ therapy. Other differences between these Groups at the therapy onset were insignificant.

Detailed data concerning auxological indices and results of hormonal tests at each analyzed time point with respect to patient's sex is presented in Table I, while depending on pretreatment diagnosis - in Table II.

Due to different withdrawal criteria, girls attained near-FH at significantly younger $\mathrm{CA}$ and BA than boys $(p<0.001)$. At the attainment of near- $\mathrm{FH}$ there was no longer BA delay observed in the total group of patients, BA/CA ratio ranged from 0.84 to 1.3, with no correlation with pre-treatment values $(r=0.008$, $p<0.05)$. The therapy duration before the attainment of near$\mathrm{FH}$ was significantly shorter and the obtained increase of height SDS was significantly worse in girls than in boys $(p=-0.03$ and $p=0.01$, respectively). Nevertheless, the difference between boys and girls in the height SDS attained at near-FH (near-FH SDS) was 0.25 , while in $\Delta \mathrm{HtSDS}$ up to near-FH it was 0.29 , that translates to $1.5-1.7 \mathrm{~cm}$ of height. Thus, despite statistical significance, both differences seem to be of limited clinical significance.

At near-FH 50 boys (52\%) and 15 girls (24\%) attained body height over $10^{\text {th }}$ centile for age of 18 years and sex (corresponding to previous criteria of rhGH therapy withdrawal), including 29 boys and 7 girls whose height exceeded $25^{\text {th }}$ centile. In 3 boys with near-FH over $50^{\text {th }}$ centile and BA 16.5 or 17.0 years, the therapy was continued during 0.4 to 1.7 years (only 1 of them decided to stop treatment before reaching BA of 18 years).

The therapy was continued up to fulfilling the withdrawal criteria in 84 patients (52 boys and 32 girls), while the remaining 76 ones (35 boys and 31 girls) decided to discontinue treatment earlier. The therapy duration after the attainment of near$\mathrm{FH}$ was longer by 2 months in girls (321 days) than in boys (262 days). Despite statistical significance $(p \leq 0.05)$, this difference seems to be of no clinical importance. There was also no significant difference in height increase in boys and girls during this phase of treatment.

Despite the fact that patients' height and the values of height SDS were significantly higher at therapy withdrawal than at near- $\mathrm{FH}(p<0.001)$, both $\Delta \mathrm{Ht}(1.1 \pm 0.8 \mathrm{~cm}$ in boys and 1.0 \pm 0.8 in girls) and $\Delta \mathrm{HtSDS}$ for CA after near-FH $(0.07 \pm 0.36$ in boys and $0.01 \pm 0.24$ in girls) seem to be insignificant from the clinical point of view.

The results concerning patient's height SDS in particular time points are shown in Figure 2.

Cumulative rhGH dose after the attainment of near-FH was very similar in boys and girls, however divided into higher number of injections in girls than in boys $(p<0.05)$. The increase of height by $1.0 \mathrm{~cm}$ at this stage of treatment required using on average $487 \mathrm{mg}$ of rhGH in 264 injections (496 mg in 248 injections in boys and $475 \mathrm{mg}$ in 287 injections in girls). There was no difference in any indices related to $\mathrm{rhGH}$ therapy effectiveness between GHD and NSD Groups.

Increased IGF-1 concentrations at the attainment of near- $\mathrm{FH}$ (i.e. IGF-1 SDS over 2.0) were observed in 39 patients (33 boys and 6 girls), including 36 ones ( 31 boys and 5 girls) from GHD Group and 3 ones ( 2 boys and 1 girl) from NSD Group. None of them presented with clinical side effects of treatment up to the end of follow-up. Reassessment of GH secretory status was performed in 62 patients ( 31 boys and 31 girls). Girls were significantly younger than boys $(p<0.001)$ that is related to different criteria of therapy withdrawal. None of the patients had GH peak in retesting below $3.0 \mu \mathrm{g} / \mathrm{l}, 8$ ones (12.9\%) had $\mathrm{GH}$ peak between 3.0 and $6.0 \mu \mathrm{g} / \mathrm{l}$, while 37 (60\%) had $\mathrm{GH}$ peak over $10.0 \mu \mathrm{g} / \mathrm{l}$. Moreover, only 2 patients from GHD Group had IGF-1 SDS in retesting below -2.0 (a boy with $\mathrm{GH}$ peak $3.99 \mu \mathrm{g} / \mathrm{l}$ and a girl with $\mathrm{GH}$ peak $9.63 \mu \mathrm{g} / \mathrm{l})$. 
Table I. Auxological and hormonal indices at the analyzed time points with respect to patients' sex

\begin{tabular}{|c|c|c|c|c|c|}
\hline \multicolumn{2}{|l|}{ Time point } & All & Boys & Girls & $p$ \\
\hline \multicolumn{6}{|l|}{ Therapy onset } \\
\hline \multicolumn{2}{|l|}{$N^{0}$ of patients } & 160 & 97 & 63 & \\
\hline \multicolumn{2}{|c|}{ Age at therapy onset [years] } & $12.3 \pm 2.2$ & $12.8 \pm 2.0$ & $11.4 \pm 2.1$ & $<0.001$ \\
\hline \multicolumn{2}{|c|}{ Height SDS at therapy onset } & $2.72 \pm 0.61$ & $2.73 \pm 0.61$ & $2.70 \pm 0.63$ & 0.81 \\
\hline \multicolumn{2}{|l|}{ TH SDS } & $1.03 \pm 0.82$ & $0.97 \pm 0.78$ & $1.11 \pm 0.88$ & 0.37 \\
\hline \multicolumn{2}{|c|}{ BA at therapy onset [years] } & $9.8 \pm 2.5$ & $10.2 \pm 2.5$ & $9.4 \pm 2.5$ & $<0.05$ \\
\hline \multicolumn{2}{|c|}{$\mathrm{BA} / \mathrm{CA}$ at therapy onset } & $0.83 \pm 0.12$ & $0.82 \pm 0.12$ & $0.85 \pm 0.12$ & 0.07 \\
\hline \multicolumn{2}{|c|}{ GH peak in stimulation tests $[\mu \mathrm{g} / 1]$} & $7.37 \pm 3.23$ & $7.06 \pm 3.68$ & $7.85 \pm 2.32$ & 0.004 \\
\hline \multicolumn{2}{|c|}{ IGF-1 SDS at therapy onset } & $1.30 \pm 1.14$ & $1.52 \pm 1.14$ & $0.96 \pm 1.06$ & $<0.001$ \\
\hline \multicolumn{6}{|l|}{ Near-FH } \\
\hline \multicolumn{2}{|l|}{ Age at near-FH [years] } & $16.3 \pm 1.4$ & $17.0 \pm 1.1$ & $15.1 \pm 0.9$ & $<0.001$ \\
\hline \multicolumn{2}{|c|}{ Therapy duration up to near-FH [years] } & $4.0 \pm 1.7$ & $4.2 \pm 1.7$ & $3.7 \pm 1.7$ & 0.003 \\
\hline \multicolumn{2}{|l|}{ Near-FH SDS } & $1.25 \pm 0.76$ & $1.15 \pm 0.77$ & $1.40 \pm 0.72$ & 0.02 \\
\hline \multicolumn{2}{|l|}{$\Delta \mathrm{HtSDS}$ up to near-FH } & $1.48 \pm 0.68$ & $1.59 \pm 0.68$ & $1.30 \pm 0.66$ & 0.01 \\
\hline \multicolumn{2}{|l|}{ BA at near-FH [years] } & $15.8 \pm 1.1$ & $16.6 \pm 0.5$ & $14.5 \pm 0.5$ & $<0.001$ \\
\hline \multicolumn{2}{|l|}{$\mathrm{BA} / \mathrm{CA}$ at near-FH } & $0.97 \pm 0.07$ & $0.98 \pm 0.07$ & $0.96 \pm 0.07$ & 0.18 \\
\hline \multicolumn{2}{|l|}{ IGF-1 SDS at near-FH } & $1.42 \pm 1.00$ & $1.66 \pm 1.04$ & $1.05 \pm 0.81$ & $<0.001$ \\
\hline \multicolumn{6}{|l|}{ Therapy withdrawal } \\
\hline \multicolumn{2}{|c|}{ Age at therapy withdrawal [years] } & $17.0 \pm 1.3$ & $17.8 \pm 1.0$ & $16.0 \pm 1.1$ & $<0.001$ \\
\hline \multicolumn{2}{|c|}{ Therapy duration after near-FH [years] } & $0.8 \pm 0.4$ & $0.7 \pm 0.4$ & $0.9 \pm 0.5$ & $<0.05$ \\
\hline \multicolumn{2}{|c|}{ Height SDS at therapy withdrawal } & $1.21 \pm 0.80$ & $1.09 \pm 0.81$ & $1.40 \pm 0.75$ & $<0.001$ \\
\hline \multicolumn{2}{|l|}{$\Delta \mathrm{HtSDS}$ after near-FH } & $0.04 \pm 0.03$ & $0.07 \pm 0.36$ & $0.01 \pm 0.24$ & 0.08 \\
\hline \multicolumn{2}{|l|}{$\Delta \mathrm{Ht}[\mathrm{cm}]$ after near-FH } & $1.1 \pm 0.8$ & $1.1 \pm 0.8$ & $1.0 \pm 0.8$ & 0.52 \\
\hline \multicolumn{2}{|c|}{ Cumulative rhGH dose after near-FH [mg] } & $527 \pm 310$ & $524 \pm 307$ & $530 \pm 318$ & 0.99 \\
\hline \multicolumn{2}{|c|}{ No of injections after near-FH } & $285 \pm 163$ & $262 \pm 143$ & $321 \pm 84$ & $<0.05$ \\
\hline \multicolumn{6}{|l|}{ Retesting } \\
\hline \multicolumn{2}{|l|}{ No of patients } & 62 & 31 & 31 & \\
\hline \multicolumn{2}{|l|}{ Age at retesting [years] } & $17.5 \pm 1.2$ & $18.2 \pm 0.9$ & $16.7 \pm 1.0$ & $<0.001$ \\
\hline GH peak in retesting $[\mu$ & & $12.3 \pm 5.9$ & $12.9 \pm 6.9$ & $11.7 \pm 4.7$ & 0.64 \\
\hline$N^{\circ}$ of patients with $\mathrm{GH}$ & $<6.0 \mu \mathrm{g} / \mathrm{l}$ & 8 & 4 & 4 & \\
\hline peak in retesting & $6.0-10.0 \mu \mathrm{g} / \mathrm{l}$ & 17 & 8 & 9 & \\
\hline & $>10.0 \mu \mathrm{g} / \mathrm{l}$ & 37 & 19 & 18 & \\
\hline IGF-1 SDS at retesting & & $0.17 \pm 0.96$ & $0.19 \pm 0.90$ & $0.16 \pm 1.0$ & 0.98 \\
\hline
\end{tabular}

$p$-values refer to the differences between boys and girls in Mann-Whitney $U$ test 
Table II. Auxological and hormonal indices at the analyzed time points with respect to pre-treatment diagnosis

\begin{tabular}{|c|c|c|c|c|c|}
\hline \multicolumn{2}{|l|}{ Time point } & All & GHD & NSD & $p$ \\
\hline \multicolumn{6}{|l|}{ Therapy onset } \\
\hline \multicolumn{2}{|l|}{$\mathrm{N}^{\circ}$ of patients } & 160 & 148 & 12 & \\
\hline \multicolumn{2}{|c|}{ Age at therapy onset [years] } & $12.3 \pm 2.2$ & $12.3 \pm 2.1$ & $12.1 \pm 3.5$ & 0.61 \\
\hline \multicolumn{2}{|c|}{ Height SDS at therapy onset } & $2.72 \pm 0.61$ & $2.68 \pm 0.59$ & $3.16 \pm 0.71$ & 0.01 \\
\hline \multicolumn{2}{|l|}{ TH SDS } & $1.03 \pm 0.82$ & $1.02 \pm 0.82$ & $1.09 \pm 0.88$ & 0.82 \\
\hline \multicolumn{2}{|c|}{ BA at therapy onset [years] } & $9.8 \pm 2.5$ & $9.8 \pm 2.4$ & $9.8 \pm 3.7$ & 0.57 \\
\hline \multicolumn{2}{|l|}{$\mathrm{BA} / \mathrm{CA}$ at therapy onset } & $0.83 \pm 0.12$ & $0.83 \pm 0.12$ & $0.82 \pm 0.13$ & 0.83 \\
\hline \multicolumn{2}{|c|}{ GH peak in stimulation tests $[\mu \mathrm{g} / \mathrm{l}]$} & $7.37 \pm 3.23$ & $6.78 \pm 2.09$ & $14.67 \pm 5.46$ & $<0.001$ \\
\hline \multicolumn{2}{|c|}{ IGF-1 SDS at therapy onset } & $1.30 \pm 1.14$ & $1.25 \pm 1.09$ & $1.89 \pm 1.53$ & 0.23 \\
\hline \multicolumn{6}{|l|}{ Near-FH } \\
\hline \multicolumn{2}{|l|}{ Age at near-FH [years] } & $16.3 \pm 1.4$ & $16.2 \pm 1.4$ & $16.5 \pm 1.8$ & 0.67 \\
\hline \multicolumn{2}{|c|}{ Therapy duration up to near-FH [years] } & $4.0 \pm 1.7$ & $4.0 \pm 1.6$ & $4.4 \pm 2.2$ & 0.74 \\
\hline \multicolumn{2}{|c|}{ Near-FH SDS } & $-1.25 \pm 0.76$ & $-1.24 \pm 0.76$ & $-1.38 \pm 0.65$ & 0.37 \\
\hline \multicolumn{2}{|l|}{$\Delta \mathrm{HtSDS}$ up to near-FH } & $1.48 \pm 0.68$ & $1.45 \pm 0.65$ & $1.78 \pm 0.95$ & 0.19 \\
\hline \multicolumn{2}{|l|}{$\mathrm{BA}$ at near-FH [years] } & $15.8 \pm 1.1$ & $15.7 \pm 1.4$ & $15.9 \pm 1.1$ & 0.43 \\
\hline \multicolumn{2}{|l|}{$\mathrm{BA} / \mathrm{CA}$ at near-FH } & $0.97 \pm 0.07$ & $0.97 \pm 0.07$ & $0.97 \pm 0.07$ & 1.00 \\
\hline \multicolumn{2}{|l|}{ IGF-1 SDS at near-FH } & $1.42 \pm 1.00$ & $1.41 \pm 0.97$ & $1.48 \pm 1.36$ & 0.83 \\
\hline \multicolumn{6}{|l|}{ Therapy withdrawal } \\
\hline \multicolumn{2}{|c|}{ Age at therapy withdrawal [years] } & $17.0 \pm 1.3$ & $17.0 \pm 1.3$ & $17.4 \pm 1.4$ & 0.60 \\
\hline \multicolumn{2}{|c|}{ Therapy duration after near-FH [years] } & $0.8 \pm 0.4$ & $0.8 \pm 0.4$ & $0.9 \pm 0.6$ & 0.34 \\
\hline \multicolumn{2}{|c|}{ Height SDS at therapy withdrawal } & $1.21 \pm 0.80$ & $1.20 \pm 0.80$ & $1.37 \pm 0.74$ & 0.29 \\
\hline \multicolumn{2}{|l|}{$\Delta \mathrm{HtSDS}$ after near-FH } & $0.04 \pm 0.03$ & $0.07 \pm 0.30$ & $0.01 \pm 0.25$ & 0.82 \\
\hline \multicolumn{2}{|l|}{$\Delta \mathrm{Ht}[\mathrm{cm}]$ after near-FH } & $1.1 \pm 0.8$ & $1.1 \pm 0.8$ & $0.0 \pm 0.8$ & 0.32 \\
\hline \multicolumn{2}{|c|}{ Cumulative rhGH dose after near-FH [mg] } & $527 \pm 310$ & $523 \pm 310$ & $576 \pm 322$ & 0.49 \\
\hline \multicolumn{2}{|c|}{ No of injections after near-FH } & $285 \pm 163$ & $281 \pm 159$ & $336 \pm 206$ & 0.34 \\
\hline \multicolumn{6}{|l|}{ Retesting } \\
\hline \multicolumn{2}{|l|}{ No of patients } & 62 & 56 & 6 & \\
\hline \multicolumn{2}{|l|}{ Age at retesting [years] } & $17.5 \pm 1.2$ & $17.5 \pm 1.2$ & $17.0 \pm 0.9$ & 0.28 \\
\hline GH peak in retesting $[\mu$ & & $12.3 \pm 5.9$ & $11.8 \pm 5.7$ & $16.9 \pm 6.0$ & $<0.05$ \\
\hline $\mathrm{N}^{\circ}$ of patients with $\mathrm{GH}$ & $<6.0 \mu \mathrm{g} / \mathrm{l}$ & 8 & 8 & 0 & \\
\hline & $6.0-10.0 \mu \mathrm{g} / \mathrm{l}$ & 17 & 16 & 1 & \\
\hline & $>10.0 \mu \mathrm{g} / \mathrm{l}$ & 37 & 32 & 5 & \\
\hline IGF-1 SDS at retesting & & $0.17 \pm 0.96$ & $0.14 \pm 0.90$ & $0.51 \pm 1.38$ & 0.22 \\
\hline
\end{tabular}

p-values refer to the differences between GHD and NSD Group in Mann-Whitney U test 


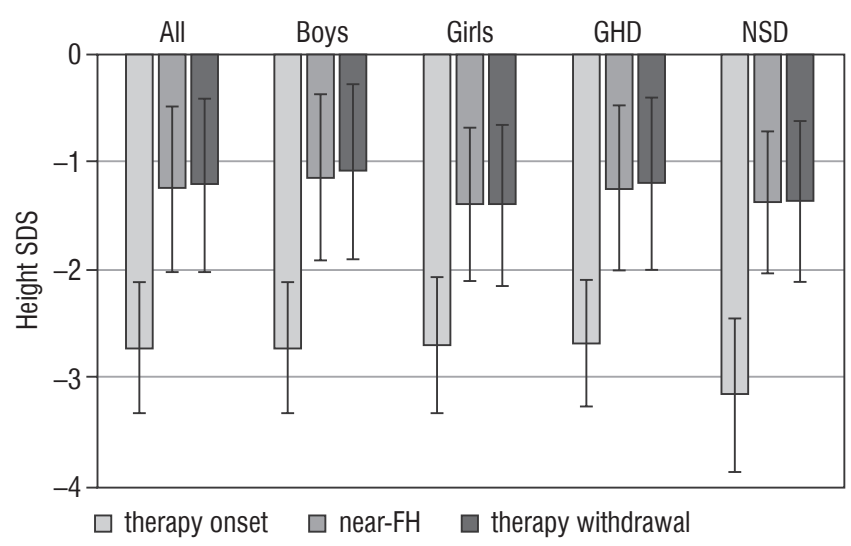

Figure 2. Height SDS of patients at therapy onset, at fulfilling the criteria of near-FH and at rhGH therapy withdrawal

\section{Discussion}

The increase of height obtained during rhGH therapy, continued with growth promoting doses after the attainment of near- $\mathrm{FH}$, is on average $1.1 \mathrm{~cm}$, with no difference between boys and girls. With respect to the total height gain during rhGH therapy, this effect is relatively small and has limited clinical significance (see Figure 2). Continuation of daily injections during - on average - over 9 months does not appear to be warranted for such effect.

In our patients' mean BA at near-FH was 16.6 years for boys and 14.5 years for girls, which - according to Bayley-Pinneau's prediction tables [17] - corresponds to about $98.5 \%$ of $\mathrm{FH}$. Thus, the limited growth promoting effect of continuation the therapy after the attainment of near-FH seems to be not surprising. Moreover, almost half of the patients willingly discontinued treatment before fulfilling the withdrawal criteria even though they might not have reached $\mathrm{FH}$ yet, which indicates that they might not have considered expected effects of continued treatment worth the related inconveniences.

In 2003, Allen and Cuttler [18] have reported that the last $1-3 \%$ of height gain during $\mathrm{rhGH}$ therapy is associated with the increase of total expenditure by $20 \%$. The cumulative amount of rhGH dispensed and the number of injections necessary to obtain additional $1.0 \mathrm{~cm}$ of height after the attainment of near$\mathrm{FH}$, recorded in our study, were also relatively high and seem to be inadequate to the obtained effects.

In our study increased IGF-1 concentrations were observed in almost $1 / 4$ of patients (39 out of 160 cases). Regarding this issue, special attention should be directed toward the study of Howard and Butler [19], who have demonstrated that increas- ing of rhGH doses after the onset of puberty has significant cost implications, without a worthwhile height gain.

It should also be mentioned that in all the studied patients the therapy in growth promoting doses should or even had to be continued inconsistently with the recommendations of $\mathrm{rhGH}$ manufacturers. This problem has been noticed by the authors of "National Program of Severe GHD Treatment in Adults and Adolescents after Completion of Growth Promoting Therapy" [20].

None of the patients subjected to retesting could be a candidate to further rhGH therapy according to the inclusion criteria of the newly implemented Therapeutic Program for the patients with confirmed severe GHD (GH peak below $3.0 \mu \mathrm{g} / \mathrm{l}$ ) [13], only $12.9 \%$ of them fulfilled the criteria of GHD for young adults $(\mathrm{GH}$ peak below $6.0 \mu \mathrm{g} / \mathrm{l}$ ) [11], while almost $60 \%$ had normal GH secretion according to the criteria for children (GH peak over 10.0 $\mu \mathrm{g} / \mathrm{l})$. Previously reported incidence of persistent severe GHD during retesting in patients with isolated GHD (with the same cut-off value for $\mathrm{GH}$ peak) was similar and had been estimated at $12.0 \%$ [21]. It has also been confirmed in other studies that the majority of patients diagnosed with isolated GHD in childhood do not fulfill the criteria of persistent severe GHD during retesting [11, 22-24], however different results have also been published [25].

The obtained results suggest that the majority of our patients could have the therapy withdrawn no later than at the attainment of near-FH. According to previous report of Loche et al. [26] and to the latest research data [27-29], normalization of $\mathrm{GH}$ secretion in children with isolated, idiopathic GHD may occur before the attainment of near- $\mathrm{FH}$. Thus, the retesting could possibly be performed earlier in order to avoid over-treatment in these patients. Short-term therapy cessation should have no negative effects even in the patients who are still $\mathrm{GH}$-deficient and should continue treatment as re-occurrence of catch-up growth after re-introduction of rhGH treatment has been observed in such situation [30].

Another problem seems the requirement of continuation of growth promoting-therapy despite advanced BA and slow HV in the patients who attained normal height, the issue concerning more than every second boy and almost every fourth girl in our study. As there is the evidence that the majority of such patients would have normal GH secretion in transition period, in fact the therapy has to be continued in subjects who are no longer either short or $\mathrm{GH}$-deficient.

It seems that there is no rationale to continue rhGH therapy in growth promoting doses in the patients with isolated, idiopathic GHD after the attainment of near-FH. An urgent need exists to determine when rhGH treatment should be interrupted and $\mathrm{GH}$ secretion re-evaluated, with the option of return to the therapy only in the case of confirmed persistent severe GHD. 


\section{References}

1. Bonjour JP, Theintz G, Buchs B, et al. Critical years and stages of puberty for spinal and femoral bone mass accumulation during adolescence. J Clin Endocrinol Metab 1991; 73: 555563.

2. Matkovic V, Jelic T, Wardlaw GM, et al. Timing of peak bone mass in Caucasian females and its implication for the prevention of osteoporosis: Inference from a cross-sectional model. J Clin Invest 1994; 93: 799808.

3. Giovannini L, Tirabassi G, Muscogiuri G, et al. Impact of adult growth hormone deficiency on metabolic profile and cardiovascular risk. Endocr J 2015; 62: 10371048.

4. Gazzaruso C, Gola M, Karamouzis I, et al. Cardiovascular risk in adult patients with growth hormone $(\mathrm{GH})$ deficiency and following substitution with GH - an update. J Clin Endocrinol Metab 2014; 99: 1829.

5. Inzaghi E, Cianfarani S. The challenge of growth hormone deficiency diagnosis and treatment during the transition from puberty into adulthood. 2013; 4: 18

6. Bengtsson BA, Johannsson G. Treatment of growth hormone deficiency in adults. JCEM 2000; 85 (Suppl.1): 933937.

7. Attanasio A, Attie K, Baxter R, et al. Consensus guidelines for the diagnosis and treatment of adults with growth hormone deficiency: Summary statement of the growth hormone research society workshop on adult growth hormone deficiency. J Clin Endocrinol Metab 1998; 83: 379381. doi: 10.1210/jcem.83.2.4611.

8. Growth Hormone Research Society. Consensus guidelines for the diagnosis and treatment of growth hormone $(\mathrm{GH})$ deficiency in childhood and adolescence: summary statement of the GH Research Society. GH Research Society. J Clin Endocrinol Metab 2000; 85: 39903993. doi: 10.1210/jcem.85.11.6984.

9. Clayton PE, Cuneo RC, Juul A, et al. Consensus statement on the management of the $\mathrm{GH}$-treated adolescent in the transition to adult care. Eur J Endocrinol 2005; 152: 165170. doi: 10.1530/eje.1.01829.

10. Ho KKY. Consensus guidelines for the diagnosis and treatment of adults with GH deficiency II: A statement of the GH Research Society in association with the European Society for Pediatric Endocrinology, Lawson Wilkins Society, European Society of Endocrinology, Japan Endocrine Society, and Endocrine Society of Australia. J Eur J Endocrinol 2007; 157: 695700. doi: 10.1530/EJE-07-0631.

11. Grimberg A, DiVall SA, Polychronakos C, et al. Guidelines for Growth Hormone and Insulin-Like Growth Factor-I Treatment in Children and Adolescents: Growth Hormone Deficiency, Idiopathic Short Stature, and Primary Insulin-Like Growth Factor-I Deficiency. Horm Res Paediatr 2016; 86: 361397. doi: 10.1159/000452150.

12. Leczenie niskorosłych dzieci z somatotropinową niedoczynnością przysadki. Załącznik B.19 do Obwieszczenia nr 65 Ministra Zdrowia w sprawie wykazu refundowanych leków, środków spożywczych specjalnego przeznaczenia oraz wyrobów medycznych. https:// www.gov.pl/attachment/c2022097-fbd3-43fc-8629-f968b509df5f (access: 31.03.2021) [in Polish].

13. Leczenie ciężkiego niedoboru hormonu wzrostu u pacjentów dorosłych oraz u młodzieży po zakończeniu terapii promującej wzrastanie. Załącznik B.111 do Obwieszczenia nr 65 Ministra Zdrowia w sprawie wykazu refundowanych leków, środków spożywczych specjalnego przeznaczenia oraz wyrobów medycznych. https:// www.gov.pl/attachment/c2022097-fbd3-43fc-8629-f968b509df5f (access: 31.03.2021) [in Polish]

14. Palczewska I NZ. Indices of somatic development of children and adolescents in Warsaw. Med Wieku Rozwoj 2001; 5 (Suppl.1): 17-118.
15. Greulich WW, Pyle SI. Radiographic Atlas of Skeletal Development of the Hand and Wrist. $2^{\text {nd }}$ ed. Stanford: Stanford University Press; 1993.

16. Elmlinger MW, Kühnel W, Weber MM, Ranke MB. Reference ranges for two automated chemiluminescent assays for serum insulin-like growth factor I (IGF-I) and IGF-binding protein 3 (IGFBP-3). Clin Chem Lab Med 2004; 42: 654664. doi: 10.1515/CCLM.2004.112.

17. Bayley N, Pinneau SR. Tables for predicting adult height from skeletal age: revised for use with the Greulich-Pyle hand standards. J Pediatr 1952; 40: 423441. doi: 10.1016/s0022-3476(52)80205-7.

18. Allen DB, Cuttler L. Clinical practice. Short stature in childhood challenges and choices. N Engl J Med 2013; 368: 12201228. doi: 10.1056/NEJMcp1213178.

19. Howard SR, Butler GE. An analysis of the clinical and cost effectiveness of growth hormone replacement therapy before and during puberty: should we increase the dose? Horm Res Paediatr 2013; 79: 7582. doi: 10.1159/000346687

20. Lewiński A, Smyczyńska J, Stawerska R, et al. National Program of Severe Growth Hormone Deficiency Treatment in Adults and Adolescents after Completion of Growth Promoting Therapy. Endokrynol Pol 2018; 69: 468524. doi: 10.5603/EP.a2018.0054

21. Smyczyńska J, Stawerska R, Lewiński A, Hilczer M. Incidence and predictors of persistent growth hormone deficiency (GHD) in patients with isolated, childhood-onset GHD. Endokrynol Pol 2014; 65: 334341. doi: 10.5603/EP.2014.0046.

22. Maghnie M, Strigazzi C, Tinelli C, et al. Growth hormone (GH) deficiency (GHD) of childhood onset: reassessment of GH status and evaluation of the predictive criteria for permanent GHD in young adults. J Clin Endocrinol Metab 1999; 84: 13241328. doi: 10.1210/jcem.84.4.5614.

23. Tauber M, Moulin P, Pienkowski C, et al. Growth hormone (GH) retesting and auxological data in $131 \mathrm{GH}$-deficient patients after completion of treatment. J Clin Endocrinol Metab 1997; 82: 352356. doi: 10.1210/jcem.82.2.3726.

24. Meazza C, Gertosio C, Pagani S, et al. Is retesting in growth hormone deficient children really useful? Minerva Endocrinol 2017; 42 325330. doi: 10.23736/S0391-1977.16.02510-4.

25. Attanasio AF, Howell S, Bates PC, et al. Confirmation of severe GH deficiency after final height in patients diagnosed as GH deficient during childhood. Clin Endocrinol (Oxf) 2002; 56: 503507. doi: 10.1046/j.1365-2265.2002.01515.x.

26. Loche S, Bizzarri C, Maghnie M, et al. Results of early reevaluation of growth hormone secretion in short children with apparent growth hormone deficiency. J Pediatr 2002; 140: 445449. doi: 10.1067/mpd.2002.122729.

27. Cavarzere P, Gaudino R, Sandri M, et al. Growth hormone retesting during puberty: a cohort study. Eur J Endocrinol 2020; 182: 559567. doi: 10.1530/EJE-19-0646.

28. Penta L, Cofini M, Lucchetti L, et al. Growth hormone (GH) therapy during the transition period: Should we think about early retesting in patients with idiopathic and isolated GH deficiency? Int J Environ Res Public Health 2019; 16: 3. doi: 10.3390/ijerph16030307.

29. Bizzarri C, Pedicelli S, Boscherini B, et al. Early retesting by GHRH + arginine test shows normal GH response in most children with idiopathic GH deficiency. J Endocrinol Invest 2015; 38: 429436. doi: 10.1007/s40618-014-0205-3.

30. Kędzia A, Majewska KA, Korcz M. Do the intervals in growth hormone therapy positively affect the growth velocity? Pediatr Endocrinol Diabetes Metab 2020; 26: 113117. doi: 10.5114/pedm.2020.97463. 